\title{
PRE MENARCHE CLASS DAN KESIAPAN MENGHADAPI MENARCHE PADA SISWA SMP
}

\author{
Risna Dewi Yanti, Ina Handayani \\ Poltekkes Kemenkes Bandung, Prodi Kebidanan Bogor, Jl. Dr. Semeru No. 116 Bogor \\ email: dewiyantirisna@gmail.com
}

\section{Pre Menarche Class and Readines of Menarche in Junior High School}

\begin{abstract}
The purpose of this study is to determine the effect of Pre-Menarche Class and menarche readiness in junior high school students in Bogor City. This research is a quantitative research with quasi experiment design that uses randomized pre and post test with control group design approach. The variables were measured using the pre-test post-test instrument. The statistical test used the dependent t test in the intervention group and the Wilcoxon test in the control group to analyze the increased readiness for menarche. The differences of the menarche readiness between intervention and control group was used independent t test. The result showed that there were significant increase of menarche readiness before and after pre-menache class with $p$ value $0.000(p<0.005)$ and so there were a significant increase of menarche readiness before and after healt education with $p$ value 0.000 ( $p$ $<0.005)$. There was an average difference between the readiness of menarche between the intervention group and the control group in which the intervention group had better eadiness withs $p 0.006$ ( $p$ $<0.005)$.
\end{abstract}

Keywords: Premenarche class, menarche readiness

\begin{abstract}
Abstrak: Tujuan penelitian ini adalah mengetahui pengaruh Pre Menarche Class terhadap kesiapan menghadapi menarche pada siswi SMP di Kota Bogor. Penelitian ini merupakan penelitian kuantitatif dengan desain quasi eksperiment, Penelitian ini menggunakan pendekatan rancangan randomized pre and post test with control grup design. Variabel diukur menggunakan instrumen pre-test post-test. Uji statistik menggunakan uji t dependen pada kelompok intervensi dan uji Wilcoxon pada kelompok kontrol untuk menganalisis peningkatan kesiapan menghadapi menarche. Sedangkan untuk menguji perbedaan peningkatan kesiapan menghadapi menarche pada kelompok intervensi dan kontrol digunakan uji $t$ independen. Hasil: Terdapat peningkatan kesiapan menghadapi menarche yang signifikan antara sebelum intervensi dan setelah intervensi pre menarche class dengan nilai $p 0.000$ $(p<0.005)$ dan begitu pula terdapat peningkatan kesiapan menghadapi menarche yang signifikan antara sebelum penyuluhan dan setelah penyuluhan dengan nilai $p 0.000(p<0.005)$. Terdapat perbedaan rerata kesiapan menghadapi menarche antara kelompok intervensi dengan kelompok kontrol dimana kelompok intervensi memiliki kesiapan yang lebih baik p $0.006(p<0.005)$.
\end{abstract}

Kata kunci: pre menarche class, kesiapan menarche

\section{PENDAHULUAN}

Masa remaja merupakan masa peralihan dari masa kanak-kanak menuju masa dewasa.yang melibatkan perubahan be+rbagai aspek seperti biologis, psikologis, dan sosial budaya (Wiknjosastro, 2013). Masa remaja penuh dengan gejolak. Gejolak ini dapat ditimbulkan oleh perkembangan pertumbuhan fisik, perubahan emosi yang lebih peka, cepat marah, agresif, perkembangan intelegensi yang makin tajam, bernalar dan makin kritis. Oleh sebab itu masa remaja seringkali disebut sebagai masa yang kritis, sehingga jika pada masa ini remaja tidak mendapatkan bimbingan dan informasi yang tepat tentang sistem, proses, dan fungsi reproduksi maka seringkali terjadi masalah yang bisa mempengaruhi masa depan remaja.

Fungsi reproduksi ketika remaja pun mulai mengalami perkembangan. Di bawah pengaruh FSH (Follicle Stimulating Hormone) yang disekresikan oleh hipofisis anterior, terjadi pematangan folikel. Hal ini berakibat pada 
peningkatan sekresi estrogen. Dimulainya sekresi estrogen menjadi tanda awitan proses pubertas seorang wanita (Wiknjosastro, 2008).

Salah satu tanda seorang perempuan telah memasuki usia pubertas adalah datangnya menstruasi pertama atau menarche, yang menjadi pertanda biologis dari kematangan seksual (Dariyo, 2004). Menarche merupakan menstruasi pertama yang biasa terjadi dalam rentang usia 10-16 tahun. Usia menarche dipengaruhi oleh faktor keturunan, keadaan gizi dan kesehatan umum (Wiknjosastro, 2013). Menarche pada remaja putri dapat menimbulkan kecemasan, ini disebabkan oleh ketidaksiapa kesiapan mental, kurang memiliki pengetahuan dan sikap yang cukup baik tentang perubahanperubahan fisik dan psikologis terkait menarche, dan kurangnya pengetahuan tentang perawatan diri yang diperlukan saat menstruasi (Ferry, 2007).

Menstruasi pertama (menarche) menjadi saat-saat yang mendebarkan bagi remaja putri karena baru pertama mengalaminya (Gunarsa, 2001). Kesiapan menghadapi menarche merupakan salah satu kondisi yang memerlukan penyesuaian visi, psikologis dan sosial dari seorang remaja putri. Kesiapan atau ketidaksiapan menghadapi menarche berdampak terhadap reaksi individual remaja putri pada saat datangnya menstruasi yang pertama. Kesiapan menghadapi menarche adalah keadaan yang menunjukkan bahwa seseorang siap untuk mencapai salah satu kematangan fisik yaitu datangnya menarche (Fajri \& Khairani, 2010). Hasil penelitian Sulistioningsih (2014) menunjukkan bahwa remaja putri yang siap menghadapi menarche sebanyak 53,3\%, dan sisanya $46,7 \%$ remaja putri tidak siap menghadapi menarche. Hal ini sejalan dengan penelitian Modjo (2013) tentang kesiapan menghadapi manarche di SMPN 1 Bone Pantai yang siap dalam menghadapi manarche $39,4 \%$, yang tidak
$60,6 \%$, penelitian tersebut juga mengungkapkan rendahnya tingkat kesiapan ini disebabkan karena kurangnya informasi atau pengetahuan. kesimpulannya terdapat hubungan antara pengetahuan tentang menstruasi dengan kesiapan remaja putri menghadapi menarche.

Remaja yang belum siap menghadapi menarche akan timbul keinginan untuk menolak proses fisiologis tersebut, mereka akan merasa haid sebagai sesuatu yang kejam dan mengancam, keadaan ini dapat berlanjut ke arah yang lebih negatif (Jayanti et all, 2011). Tetapi berbeda bagi mereka yang telah siap dalam menghadapi menarche, mereka akan merasa senang dan bangga, dikarenakan mereka menganggap dirinya sudah dewasa secara biologis (Suryani \&Widyasih, 2008).

Hasil dari beberapa penelitian yang dilakukan Aboyeji et all (2005), menunjukan bahwa kebanyakan remaja mempunyai harapan yang lebih negatif terhadap menstruasi pertama (menarche) dan merespon menstruasi pertama (menarche) secara negatif. Hal ini dideskripsikan oleh subjek dengan perasaan secara negatif seperti merasa takut, terkejut, sedih, kecewa, malu khawatir dan bingung (Fajri \& Khairani, 2010).

Secara umum disimpulkan bahwa dapat kesiapan dalam menghadapi menarche terdiri dari kesiapan pengetahuan dan kesiapan sikap. Pengetahuan adalah hasil pengindraan manusia atau hasil tahu seseorang terhadap objek melalui indera yang dimilikinya (mata, hidung, telinga, dan sebagainya) (Notoatmodjo, 2010). Pengetahuan yang diperoleh remaja tentang menstruasi akan mempengaruhi sikap remaja tentang menarche. Jika sikap yang dibentuk remaja tentang $m e$ narche positif, maka hal ini akan berpengaruh pada kesiapan remaja dalam menghadapi $m e$ narche (Fajri \& Khairani, 2010).

Untuk mempersiapkan pada remaja putri saat menghadapi menarche diperlukan peran 
orang tua maupun guru di sekolah untuk memberikan informasi yang benar tentang kondisi perubahan pada masamasa remaja (Dariyo, 2004). Selain itu, diperlukan pemberian informasi kesehatan reproduksi remaja (KRR) khususnya tentang menstruasi karena informasi KRR masih sangat kurang (BKKBN, 2005).

Remaja yang belum mendapatkan pengetahuan dan informasi yang benar tentang menstruasi sehingga memiliki informasi yang salah tentang menstruasi, bahkan cenderung mengkaitkan menstruasi dengan sesuatu yang negatif. Ketidaktahuan anak tentang menstruasi dapat mengakibatkan anak sulit untuk menerima menarche (Budiati \& Apriastuti, 2012).

Berdasarkan kajian tersebut maka diperlukan usaha untuk memberikan pendampingan pre menarche kepada remaja untuk memberikan pengetahuan dan membentuk sikap yang positif tentang menarche. Salah satu usaha yang bisa dilakukan adalah membentuk wadah berupa pre menarche class yaitu memberikan pendampingan kepada kelompok remaja usia pre menarche yang terdiri 10-15 orang. Menurut Proverawati dan Misaroh (2009), usia menarche rata-rata adalah 11-12 tahun. Pada usia tersebut seorang remaja berada pada tingkat Sekolah Menengah Pertama (SMP) kelas VII, sehingga pelaksanaan pre menarche class bisa dilakukan pada remaja SMP VII.

Tujuan penelitian ini untuk mengetahui pengaruh pre menarche class terhadap kesiapan menghadapi menarche pada siswiSMP di Kota Bogor.

\section{METODE PENELITIAN}

Penelitian ini merupakan penelitian kuantitatif dengan desain quasi eksperiment, Penelitian ini menggunakan pendekatan rancangan randomized pre and post test with control, yaitu dengan memberikan suatu bentuk intervensi yaitu pre menarche class kemudian dilihat pengaruhnya terhadap kesiapan menghadapi menarche, hasilnya dibandingkan dengan kelompok kontrol yaitu kelompok yang tidak diberikan pre menarche class.

Populasi dalam penelitian ini adalah keseluruhan dari subjek penelitian yaitu seluruh siswi SMP di kota Bogor. Subjek penelitian ini adalah Seluruh siswi SMP Negeri di kota Bogor yang memenuhi kriteria inkusi dan tidak termasuk dalam kriteria eksklusi

Besar sampel minimal dihitung dengan menggunakan rumus besar sampel penelitian analisis numerik tidak berpasangan dan didapatkan 42 sampel perkelompok, dengan jumlah sampel total adalah 84 orang

Pengambilan sampling pada penelitian ini yaitu menggunakan teknik Cluster Sampling. Di kota Bogor terdapat 20 SMP Negeri, maka dari 20 tersebut diambil secara acak sebanyak 2 SMP Negeri. yang kemudian kedua SMP tersebut akan diacak juga untuk menentukan mana yang akan menjadi kelompok kontrol dan kelompok intervensi. Dari proses pengambilan sampel diatas maka diperoleh hasil yang menjadi kelompok kontrol adalah SMPN 6 Bogor dan yang menjadi kelompok intervensi adalah SMPN 5 Bogor.

Pengumpulan data primer pada penelitian ini dibagi dalam 2 kelompok, yaitu : a. untuk prosedur intervensi penelitian pada kelompok intervensi dijelaskan sebagai berikut: 1) Preintervensi, Pada langkah pre intervensi subjek diukur tingkat kesiapan menghadapi menarche dengan menggunakan kuisioner, 2) Intervensi. Selanjutnya siswi akan diberikan pengetahuan tentang konsep dasar menarche dan persiapan dalam menghadapi menarche. Kelompok intervensi dengan metode kelompok kecil yaitu pre menarche class dan kelompok kontrol dalam bentuk penyuluhan kelas besar. Intervensi pre menarche class dan penyuluhan pada kelompok kontrol dilakukan selama 3 kali pertemuan, 
dimana satu kali pertemuan berlangsung dengan durasi 1 jam, dengan rincian kegiatan sebagai berikut: 5 menit pembukaan, 20 menit pemberian materi, 30 menit diskusi dan tanya jawab, 5 menit penutup. Metode pre menarche class ini lebih menekankan pendekatan personal untuk diskusi dan tanya jawab karena responden yang dibagi kedalam kelompok kecil, sehingga waktu diskusi dan tanya jawab lebih lama dibandingkan dengan waktu pemberian materi. Setiap kelompok pre menarche berjumlah 12-15 orang responden. Adapun topik yang diberikan adalah sebagai berikut: a) Pertemuan 1 : Perubahan Fisik Remaja dan proses adaptasi menghadapi perubahan tersebut; b) Pertemuan 2 : Perubahan Psikologis Remaja dan proses adaptasi menghadapi perubahan tersebut; c) Pertemuan 3 : Persiapan diri menghadapi perubahan fisik dan psikologis. 3) Post intervensi. Setelah melakukan intervensi sebanyak 3 kali pertemuan subjek diukur kembali tingkat kesiapan menghadapi menarche dengan menggunakan kuisioner.

Pada kelompok kontrol, prosedur pengumpulan data dilakukan melalui pre test dan post test. Setelah dilakukan pre test pada kelompok kontrol diberikan penyuluhan tentang pre menarche dalam bentuk kelas besar, sebanyak 3 kali pertemuan dengan durasi 1 jam. Setelah mengikuti 3 kali pertemuan penyuluhan maka responden diberikan post test. Penerapan prinsip keadilan pada kelompok kontrol adalah dengan memberikan materi penyuluhan yang sama dengan materi pre menarche class.

Analisis data dilakukan untuk mengetahui perbandingan antara variabel independen dengan dependen, yaitu peningkatan kesiapan pada kelompok intervensi pre menarche class dan kelompok kontrol. Adapun langkah yang dilakukan antara lain: 1) mencari rerata kesiapan kedua kelompok, 2) mencari selisih kesiapan sebelum dan sesudah perlakuan pada kedua kelompok, 3) melakukan uji normalitas data pada setiap data yang akan diuji dengan hasil data yang berdistribusi normal adalah data kesiapan setelah perlakuan pada kelompok kontrol, data sebelum dan setelah perlakuan pada kelompok intervensi, data peningkatan kesiapan kelompok kontrol dan kelompok intervensi, sedangkan data yang berdistribusi tidak nornal adalah data kesiapan sebelum perlakuan pada kelompok kontrol, 4) Setelah itu akan dilakukan uji $t$-dependent untuk melihat perbedaan rata-rata kesiapan menghadapi menarche sebelum dan setelah perlakuan pada kelompok intervensi dan dilakukan uji Wilcoxon pada kelompok kontrol, 5) Langkah terakhir adalah melakukan uji $t$-independent dengan menggunakan data selisih nilai kesiapaan pre dan post pada kedua kelompok untuk mengetahui pengaruh pre menarche class terhadap kesiapan menghadapi menarche.

\section{HASIL PENELITIAN}

Berdasarkan Tabel 1 karakteristik responden penelitian terbanyak berusia 12 tahun yaitu $87 \%$ dan sebagian besar sudah memperoleh informasi tentang menarche yaitu $81 \%$. Adapun sumber informasi menarche sebagian besar diperoleh dari orang tua yaitu $35,5 \%$.

Berdasarkan Tabel 2 diketahui bahwa terdapat peningkatan kesiapan remaja menghadapi menarche setelah mengikuti pre menarche class dengan rerata yang semula 137 menjadi 155,62 .

Kesiapan menghadapi menarche pada penelitian ini digambarkan dengan nilai mean 137 pada kelompok intervensi sebelum dilakukan premenarche class dan nilai mean 155,62 diperoleh setelah dilakukan intenvensi. Hal ini menunujukan adanya peningkatan nilai kesiapan responden dalam menghadapi menarche. Hal yang sama ditujukan pula pada kelompok kontrol yang diberikan pengetahuan tentang menarche melalui metode penyuluhan, dimana nilai kesiapan 
sebelumnya adalah 141,68 dan nilai kesiapan sesudah penyuluhan adalah 153,26. Kedua kelompok mendapatkan kenaikan nilai kesiapan menghadapi menarche, tetapi pada kelompok intervensi pre menarche class yang didapatkan nilai maksimum 180 yang merupakan penilaian tertinggi kesiapan menghadapi menarche.

Pada Tabel 3 diperoleh adanya peningkatan kesiapan pada kelompok Intervensi pada saat sebelum dan sesudah intervensi. Didapatkan

Tabel. 1 Karakteristik Subjek Penelitian

\begin{tabular}{lcccc}
\hline \multicolumn{1}{c}{ Karakteristik } & $\begin{array}{c}\text { Kelompok } \\
\text { Intervensi } \\
\mathbf{n = 4 5}\end{array}$ & $\begin{array}{c}\text { Kelompok } \\
\text { Kontrol } \\
\mathbf{n = 4 5}\end{array}$ & $\begin{array}{c}\text { Total } \\
\mathbf{n = 9 0}\end{array}$ & $\mathbf{\%}$ \\
\hline Usia & 5 & & & \\
11 Tahun & 37 & 2 & 7 & 8 \\
12 Tahun & 3 & 41 & 78 & 87 \\
13 Tahun & & 2 & 5 & 5 \\
Pengetahuan menarche & 38 & & & \\
Tahu & 7 & 10 & 73 & 81 \\
Tidak tahu & & & 17 & 19 \\
Sumber informasi Menarche & 19 & 13 & & \\
Ibu & 4 & 7 & 32 & 35,5 \\
Guru & 6 & 9 & 11 & 12,2 \\
Teman & 9 & 6 & 15 & 16,7 \\
Internet & 7 & 10 & 17 & 16,7 \\
Tidak mendapat informasi & 7 & & & \\
\hline
\end{tabular}

Tabel 2. Gambaran Kesiapan Menghadapi Menarche pada Siswi SMP di Kota Bogor

\begin{tabular}{lcccc}
\hline \multirow{2}{*}{ Kelompok } & \multicolumn{2}{c}{$\begin{array}{c}\text { Intervensi } \\
\mathbf{n = 4 5}\end{array}$} & \multicolumn{2}{c}{$\begin{array}{c}\text { Kontrol } \\
\mathbf{n = 4 5}\end{array}$} \\
\cline { 2 - 5 } & Sebelum & Sesudah & Sebelum* & Sesudah \\
\hline Median & 136 & 154 & $\mathbf{1 4 2}$ & 153 \\
Nilai Minimum & 114 & 124 & $\mathbf{1 1 8}$ & 126 \\
Nilai Maksimum & 157 & 180 & $\mathbf{1 6 3}$ & 177 \\
Mean & $\mathbf{1 3 7}$ & $\mathbf{1 5 5 , 6 2}$ & 141,68 & $\mathbf{1 5 3 , 2 6}$ \\
SD & $\mathbf{1 0 , 9 1}$ & $\mathbf{1 3 , 2 3}$ & 11,49 & $\mathbf{1 2 , 8 6}$ \\
\hline
\end{tabular}

Tabel 3. Hasil Analisis Perbedaan Kesiapan Menghadapi Menarche Pada Kelompok Intervensi

\begin{tabular}{lccc}
\hline \multicolumn{1}{c}{ Kelompok } & $\mathbf{n}$ & $\begin{array}{c}\text { Rerata } \\
\text { (simpangan baku) }\end{array}$ & $\mathrm{p}^{*}$ \\
\hline Kesiapan Sebelum Intervensi & 45 & $137(10,91)$ & 0,000 \\
Kesiapan Setelah Intervensi & 45 & $155,62(13,62)$ & \\
\hline
\end{tabular}


Tabel 4. Hasil Analisis Perbedaan Kesiapan Menghadapi Menarche Pada Kelompok Kontrol

\begin{tabular}{lccc}
\hline \multicolumn{1}{c}{ Kelompok } & $\mathbf{n}$ & $\begin{array}{c}\text { Median } \\
\text { (Minimum-Maksimum) }\end{array}$ & $\mathrm{p}^{*}$ \\
\hline Kesiapan Sebelum & 45 & $142(118-163)$ & 0,000 \\
Kesiapan Setelah & 45 & $153(126-177)$ & \\
\hline
\end{tabular}

Tabel 5. Hasil Analis Perbedaan Peningkatan Kesiapan Menghadapi Menarche Pada Kelompok Intervensi dan Kontrol

\begin{tabular}{lccc}
\hline \multicolumn{1}{c}{ Kelompok } & $\mathbf{n}$ & $\begin{array}{c}\text { Rerata } \\
\text { (simpangan baku) }\end{array}$ & $\mathrm{p}^{*}$ \\
\hline Peningkatan Kelompok intervensi & 45 & $17,84(12,0)$ & 0,006 \\
Peningkatan Kelompok kontrol & 45 & $11,57(12,86)$ & \\
\hline
\end{tabular}

peningkatan kesiapan dengan rerata 137 menjadi 155,62. Dari hasil analisis dengan mengunakan uji $t$ dependen didapatkan hasil terdapat peningkatan kesiapan menghadapi menarche yang signifikan antara sebelum intervensi dan setelah intervensi dengan nilai $\mathrm{p} 0.000(\mathrm{p}<0.005)$.

Pada Tabel 4 diperoleh adanya peningkatan kesiapan pada kelompok Intervensi pada saat sebelum dan sesudah intervensi. Didapatkan peningkatan kesiapan dengan rerata 142 menjadi 153. Dari hasil analisis dengan mengunakan uji Wilcoxon didapatkan hasil terdapat peningkatan kesiapan menghadapi menarche yang signifikan antara sebelum penyuluhan dan setelah penyuluhan dengan nilai $\mathrm{p} 0.000(\mathrm{p}<0.005)$.

Pada Tabel 5 hasil analisis dengan mengunakan uji tindependen didapatkaan hasil terdapat perbedaan rerata kesiapan menghadapi menarche antara kelompok intervensi dengan kelompok kontrol dimana kelompok intervensi memiliki kesiapan yang lebih baik. Dengan kata lain pre menarche class memiliki pengaruh yang signifikan terhadap peningkatan kesiapan dibandingkan dengan kelompok intervensi dengan nilai $\mathrm{p} 0.006(\mathrm{p}<0.005)$.

\section{PEMBAHASAN}

Pada penelitian ini pada kelompok intervensi dengan metode pre menarche class dan pada kelompok kontrol dengan metode penyuluhan sama-sama terdapat peningkatan yang signifikan dalam hal kesiapan menghadapi menarche.

Berdasarkan penelitian Leliana (2010) tentang hubungan pengetahuan terhadap kesiapan mengahadapi menarche yang menyatakan ada hubungan positif dan signifikan antara pengetahuan terhadap kesiapan remaja putri. Semakin baik pengetahuan seseorang, maka semakin siap seseorang menghadapi $m e$ narche.

Darvill \& Powell (2003) mengemukakan bahwa ilmu pengetahuan dapat memberikan rasa aman kepada manusia. Pengetahuan mengenai reproduksi memberitahukan apa yang dialami oleh seorang perempuan yang sedang dalam masa puber adalah normal. Adanya perasaan bingung saat pertama kali mengalami menstruasi disebabkan oleh remaja putri tersebut kurang pengetahuan tentang menstruasi. Ketidaktahuan anak tentang menstruasi dapat mengakibatkan anak sulit untuk menerima menarche (Budiati \& Apriastuti, 2010)

Berdasarkan hasil-hasil penelitian tersebut sejalan dengan penelitian ini yaitu bahwa pemberian infomasi memberikan tambahan pengetahuan untuk responden dalam menghadapi menarche seperti yang ditunjukan pada data gambaran kesiapan menghadapi menarche pada 
penelitian ini dimana terjadi peningkatan kesiapan menghadapi menarche baik pada responden dengan premenarche class maupun penyuluhan.

Pada penelitian ini hasil analisis dengan mengunakan uji $t$ independen didapatkaan hasil terdapat perbedaan rerata kesiapan menghadapi menarche antara kelompok intervensi dengan kelompok kontrol dimana kelompok intervensi memiliki kesiapan yang lebih baik.

Kesiapan menghadapi menarche merupakan salah satu kondisi yang memerlukan penyesuaian fisi, psikologis dan sosial dari seorang remaja putri. Kesiapan atau ketidaksiapan menghadapi menarche berdampak terhadap reaksi individual remaja. Ketidaksiapan tersebut disebabkan oleh ketidaktahuan remaja putri tentang perubahanperubahan fisiologis yang terjadi saat remaja sehingga menstruasi dianggap sebagai hal yang tidak baik (Dariyo, 2004), kesiapan mental dan kurangnya pengetahuan tentang perawatan diri yang diperlukan saat menstruasi (Ferry, 2007).

Untuk mengatasi ketidaksiapan remaja putri saat menghadapi menarche diperlukan : Komunikasi (Hurlock, 2004) Pemberian informasi tentang kesehatan reproduksi dari orangtua maupun guru di sekolah (Dariyo, 2004) dan keterbukaan antara guru, murid, dan orangtua dalam membicarakan kesehatan reproduksi (BKKBN, 2005) serta pemberian informasi kesehatan reproduksi remaja (KRR) khususnya tentang menstruasi melalui penyuluhan (Depkes, 2000).

Informasi KRR khususnya tentang menstruasi yang diberikan harus benar, karena menstruasi merupakan peristiwa yang sangat penting bagi remaja putri yang menjadi tanda dari kematangan seksual dan erat hubungannya dengan fungsi reproduksi (Kartono, 2006). Selain pemberian informasi KRR dari guru dan orangtua, informasi tentang KRR yang benar khususnya menstruasi juga dapat diperoleh melalui ceramah, diskusi, media cetak (majalah, koran) dan media elektronik.
Pemberian informasi pre menarche di beberapa sekolah yang sudah berjalan saat ini adalah dengan metode penyuluhan dalam kelas besar. Seluruh Siswi dikumpulkan di suatu ruangan dalam suatu waktu dan diberikan materi tentang kesehatan reproduksi remaja dimana salah satu didalamnya terdapat materi menarche. Metode penyuluhan ini hanya mempersiapkan satu aspek kesiapan yaitu aspek pemahaman, namun dua aspek lainnya yaitu penghayatan belum tersentuh.

Untuk itu diperlukan metode pemberian informasi menarche yang dapat melingkupi tiga aspek kesiapatan tersebut. salah satu metode yang bisa dilakukan adalah metode pendampingan dalam wadah pre menarche class. Dalam Pre Menarche Class ini seluruh remaja yang belum mendapakan menstruasi dikelompokan dalam kelompok kecil terdiri dari 10-15 orang. Mereka mendapatkan pendampingan selama 3 kali pertemuan dengan muatan materi yang hanya terfokus pada persipan menarche. Satu kali pertemuan dialokasikan selama 1-1,5 jam dengan susunan kegiatan antara lain pembukaan, materi, diskusi. Dalam sesi diskusi lebih diarahkan pada pendekatan psikologis untuk menumbukan kesiapan remaja menghadapi menarche.

\section{PENUTUP}

Berdasarkan hasil penelitian yang dilakukan dan hasil analisa data yang diperoleh dapat diambil kesimpulan bahwa terdapat peningkatan kesiapan menghadapi menarche yang signifikan antara sebelum intervensi dan setelah intervensi pre menarche class selain itu terdapat perbedaan rerata kesiapan menghadapi menarche antara kelompok intervensi dengan kelompok kontrol dimana kelompok intervensi memiliki kesiapan yang lebih baik.

Berdasarkan hasil penelitian dan beberapa keterbatasan penelitian ini, maka peneliti 
memberikan saran sebagai berikut: 1) diperlukan upaya penyebaran informasi mengenai pentingnya pemberian pengetahuan tentang menarche dalam rangka meningkatkan kesiapan diri remaja, 2) diharapkan pre menarche class ini dapat dijadikan sebagai salah satu cara untuk mempersiapkan remaja menghadapi menarche, 3) secara khusus untuk melibatkan peran serta aktif orangtua dan guru untuk mempersiapkan remaja menghadapi menarche, 4) perlu adanya penelitian yang lebih jauh untuk meneliti faktor lain yang mempengaruhi kesiapan menghadapi menarche.

\section{DAFTAR PUSTAKA}

BKKBN. (2000). Buku Pedoman Kesehatan Reproduksi Remaja (KRR) Adolescent Reproductive Health (ARH). Semarang : BKKBN

BKKBN. (2005). Remaja Memerlukan Informasi Kesehatan Reproduksi. Available online: http://www.bkkbn.go.id/Webs/ DetailRubrik.aspx?MyID =2126.

Budiati, S., Apriastuti, Anita. (2012). Hubungan Tingkat Pengetahuan Ibu Tentang Kesehatan Reproduksi Remaja Dengan Kesiapan Anak Menghadapi Masa Pubertas. Akademi Kebidanan Estu Utomo Boyolali. http://journal.akbideub.ac.id/ index.php/jkeb/article/view/58/57.

Dariyo A. (2004). Psikologi Perkembangan Remaja. Bogor : Ghalia Indonesia

Depkes. (2000). Buku Pegangan Fasilitator dan Tehnik Penyampaian Materi Inti Kesehatan Reproduksi Remaja. Jakarta : Depkes

Fajri, Ayu., Khairani, M. (2010). Hubungan Antara Komunikasi Ibu dan Anak Dengan Kesiapan Menghadapi Menstruasi Pertama (Menarche) Pada Siswi SMP Muhammadiyah Banda Aceh. http://ejournal. undip.ac.id/index.php/psikologi/article/ download/2885/2568.

Ferry. (2007). Koping Adaptasi Menarche Sebagai Strategi Peningkatan Kesehatan Reproduksiu Remaja. Available online : http://ferryefendi.blogspot.com/2007/11/ koping-adaptasimenarche-sebagai.html.

Gunarsa, S.D. (2001). Psikologi Praktis: Anak, Remaja dan Keluarga. Jakarta: Gunung Mulia.

Hurlock. (2004). Suatu Pendekatan Sepanjang Rentan Kehidupan. Edisi V. Jakarta : Erlangga

Jayanti, Nur Fitria., Purwanti, Sugi. (2011). Deskripsi Faktor-faktor Yang Mempengaruhi Kesiapan Anak Dalam Menghadapi Menarche Di SD Negeri 1 Kretek Kecamatan Paguyangan Kabupaten Brebes. Akademi Kebidanan YLPP Purwokerto. http://ojs.akbidylpp.ac.id/ index.php/Prada/article/viewFile/11/10.

Kartono K. (2006). Psikologi Wanita 1 Mengenal Gadis Remaja dan Wanita Dewasa. Bandung : CV Mandar Maju

Leliana. (2010). Hubungan Pengetahuan Remaja Putri Terhadap Kesiapan Dalam Menghadapi Menarche di SD AL-Azhar Medan. http://repository.usu.ac.id/handle/ 123456789/19364.

Modjo, D. (2013). Hubungan pengetahuan tentang menstruasi dengan kesiapan remaja putri menghadapi menarche di SMP N 1 Bone Pantai. THESIS. Universitas Negeri Gorontalo

Notoatmodjo. (2010). Promosi Kesehatan Teori Dan Aplikasi. edisi revisi. Jakarta: Rineka Cipta.

Proverawati, A., \& Misaroh, S. (2009). Menarche menstruasi pertama penuh makna. Yogyakarta: Nuha Medika.

Sulistioningsih, E. (2014). Hubungan Kesiapan Menghadapi Menarche dengan Perilaku 
Vulva Hygiene Remaja Putri di Sekolah Dasar Negeri (SDN) Kebonsari 04 Kecamatan Sumbersari Kabupaten Jember.

Suryani, E., Widyasih, H. (2008). Psikologi Ibu dan Anak. Jakarta: Fitramaya.
Wiknjosastro H. (2013). Ilmu Kandungan. Jakarta : Yayasan Bina Pustaka Sarwono Prawirohardjo

Wiknjosastro, G. H. (2008). Asuhan Persalinan Normal. 